\title{
Hidrofugación de rocas carbonatadas porosas: Propiedades que controlan su eficacia
}

\section{Waterproofing of porous carbonate rocks: Efficiency- controlling its properties}

\author{
R.M. ESBERT, JOSÉ ALONSO SÁNCHEZ \\ Dpto. de Geología (Petrología). Univ.de Oviedo
}

\section{RESUMEN}

La finalidad del presente estudio es la de tratar de establecer que propiedades fisicas pueden ser empleadas de una forma rutinaria para conocer el grado de eficacia de un tratamiento aplicado sobre un determinado sustrato pétreo.

Con esta finalidad se han seleccionado dos tipos de rocas carbonatadas, la caliza de Hontoria (Burgos) y la dolomía de Laspra (Asturias), con una configuración del sistema poroso muy diferente. Se han empleado tres productos protectores de naturaleza silicoorgánica, ampliamente utilizados, dos siloxanos y un copolimero.

Las propiedades seleccionadas (ángulo de contacto y permeabilidad al vapor de agua) han resultado idóneas para determinar el grado de eficacia de los distintos tratamientos. Se ha comprobado que dicho grado está condicionado por las características quimicas del producto, siendo prácticamente nula la influencia de las caracteristicas de la roca.

Se están llevando a cabo otras investigaciones con las mismas piedras y productos de tratamiento en un intento de establecer correlaciones entre el grado de eficacia de dichos tratamientos y la durabilidad de los sistemas piedratratamiento.

\begin{abstract}
The aim of this study is to establish which physical properties may be used, in a routine way, in order to know the efficacy rate of a treatment applied on a specific rocky substrate.
\end{abstract}

Whit this purpose. two types of carbonated rocks, the limestone of Hontoria (Burgos) and the dolomite of Laspra (Asturias) have been chosen, with a very different configuration of their porosity systems. Three protection products, with silico-organic nature and widely used have been used, to wit: two siloxenes and a copolymer.

Tue properties chosen (contact angle and water vapour permeability) have been the proper ones in order to determine the efficacy level of the different treatments. This level was demonstrated to be conditioned by the chemical characteristics of this product, and the influence of the characteristics is practically null.

Other investigations are being carried out with the same rocks and treatmen products in order to stablish the corelationships between the efficacy rate of these treatments and the durability of the rock-treatment systems.

\section{1.- INTRODUCCIÓN}

La atmósfera, en especial en las áreas urbanas suele ser muy agresiva principalmente a causa de la contaminación. Cuando se plantea la restauración de la piedra de edificación o la utilización de ésta como roca de revestimiento, surge la necesidad de protegerla de la acción de los agentes presentes en estas atmósferas contaminadas. Los productos actualmente empleados con esta finalidad se los conoce bajo el nombre genérico de hidrofugantes. Su acción fundamental es repeler el agua que entra en contacto con la superficie de la piedra expuesta ya que ésta es el principal agente alterante, tanto por ella misma como por los productos que puede llevar en disolución o en suspensión. Entre éstos tienen un papel destacado los contaminantes.

\section{1.- INTRODUCTION}

The atmosphere, particularly in urban areas, is usually very aggressive, mainly as a result of pollution. When considering the restoration of building stone or its use as coating rock, it is necessary to protect it from the action of agents that are present in this polluted atmosphere. The products currently employed for this purpose are known under the generic name of water repellents or hydrofuging agents. Their main action is to repel the water that enters in contact with the surface of exposed stone, since this water is the main weathering agent, due to its natural effects and to the dissolved or suspended products it may contain, pollutants in particular. 
A lo largo del tiempo se han utilizado como protectores productos de naturaleza diversa (Rossi Manaresi, 1993). En la actualidad la mayoría son productos manufacturados por la industria química, presentan composición variable aunque su objetivo común es la hidrofugación de la superficie tratada.

La variedad de composiciones y de sustratos pétreos sobre los que se aplican los hidrofugantes, hace pensar que éstos no puedan ser empleados de una manera aleatoria. Se debe conocer de que manera afectan a cada tipo de piedra (Alessandrini y Tabasso, 1993; De White et al., 1993; Esbert, 1993) y cómo va a evolucionar la piedra tratada con el tiempo.

Bajo esta perspectiva se ha enfocado el presente trabajo que se pretende pueda servir de ejemplo, para el estudio del comportamiento de sustratos pétreos carbonatados sobre los que se han aplicado tratamientos hidrofugantes de distinta naturaleza química.

Las rocas seleccionadas tienen porosidad y configuración del sistema poroso muy diferentes (Apartado 3), y pueden considerarse como prototipos. Son la dolomía de Laspra (Asturias) y la caliza de Hontoria (Burgos), ambas utilizadas en monumentos significativos del patrimonio arquitectónico español.

Las propiedades físicas seleccionadas han sido el ángulo de contacto y permeabilidad al vapor de agua, ambas relacionadas con la eficacia y durabilidad de los sistemas piedra - tratamiento. Son propiedades fáciles determinar por lo que se podría aconsejar su cálculo, de una manera sistemática, cuando se realice el estudio de las características de un hidrofugante aplicado a un sustrato pétreo.

Los productos aplicados son tres de los más empleados actualmente como hidrofugantes en el ámbito europeo: dos siloxanos, de distinta casa comercial, y un copolímero (siloxano-acrilato).

\section{2.- PROPIEDADES ESTUdIADAS: ÁNGULO DE CONTACTO Y PERMEABILIDAD AL VAPOR DE AGUA}

$\mathrm{El}$ ángulo de contacto es una propiedad directamente relacionada con las características hidrorrepelentes de la superficie de un sólido.

Una gota de agua tiende a adoptar una forma esférica. Si esta gota se coloca sobre una superficie plana, el casquete que se forme será más similar a una esfera completa cuanto mayor sea la capacidad hidrófoba del material, es decir, el ángulo de contacto entre la piedra
Different protecting products have been used over the years (Rossi Manaresi, 1993). Today the majority of these products are manufactured by the chemical industry. Compositions vary, but their common aim is the hydrofuging of the treated surface.

The variety of compositions and stone varieties treated with hydrofuging agents would seem to indicate that these products may not be used randomly. A knowledge of how they affect each type of stone (Alessandrini and Tabasso, 1993; De White et al., 1993; Esbert, 1993) and of the long-term evolution of the treated stone is required.

The above perspective has been adopted for the present paper, which we hope may serve as an example for the study of carbonate stones subjected to different chemical hydrofuging treatments.

The porosity and porous system configuration of the selected rocks, which may be considered as prototypes, are very different (Section 3). These rocks are Laspra dolomite (Asturias) and Hontoria limestone (Burgos), both of them used in important monuments of the Spanish architectural heritage.

Contact angle and water vapour permeability were the selected physical properties. Both are related to stone treatment efficiency and durability. These properties are easy to determine, and their calculation is thus advisable when studying the characteristics of any hydrofuging agent that is to be applied to a stone surface.

The applied products are three of the most common hydrofuging agents used in Europe today: two siloxanes, supplied by different manufacturers, and one copolymer (siloxane-acrylate).

\section{2.- STUDIED PROPERTIES: CONTACT ANGLE AND WATER VAPOUR PERMEABILITY}

The contact angle property is directly related to the hydro-repellent characteristics of a solid's surface.

A drop of water tends to be spherical in shape. If such a drop lodges on a flat surface, the resulting cap will be more or less similar to a complete sphere, depending on the material's hydrophobic capacity; that is, the greater the surface's hydrorepellent 
y el agua será mayor cuanto mayor sea la capacidad hidrorrepelente de la superficie (Fig. 1) (De Castro, 1980).

El ángulo de contacto se calcula a partir de la medida del diámetro del círculo que forma la gota sobre la superficie de la piedra (a) y la altura de la misma $(\mathrm{H})$ (Fig. 2). La expresión matemática utilizada es:

$$
\theta=2 \operatorname{arctg} \frac{2 \mathrm{H}}{\mathrm{a}}
$$

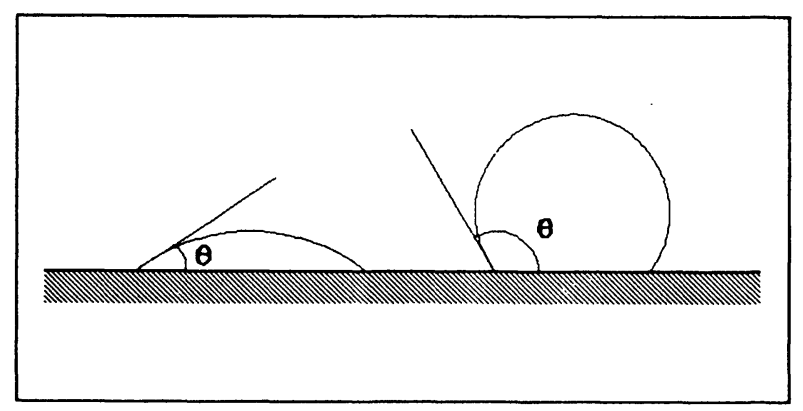

Fig. 1.- Se representa el aumento del ángulo de contacto entre las piedras sin tratar (izquierda) y después de ser aplicado un tratamiento hidrofugante (derecha).

Fig.1.- Increase of the contact angle between non-treated stones (left) and stones after treatment with a hydrofuging agent (right) is shown.

\section{Procedimiento de medida}

Sobre la superficie tratada, se deja caer una gota de agua de $5 \mu \mathrm{l}$. desde una altura de $1 \mathrm{~cm}$. Posteriormente y con la ayuda de una lupa con un retículo graduado se mide "a" $y$ " $H$ ".

Habitualmente, para sustratos carbonatados una media de diez medidas por muestra resulta suficientemente representativo.

La permeabilidad al vapor de agua se define como la cantidad de vapor de agua que fluye, por unidad de tiempo y de superficie, y en condiciones estacionarias, a través de un cuerpo de espesor dado; entre dos superficies paralelas y normalmente a las mismas, y bajo el efecto de una diferencia de presión parcial de vapor de agua entre las dos superficies (Normal 21/85). capacity, the greater the contact angle between stone and water will be (Fig. 1) (De Castro, 1980).

The contact angle is calculated from the diameter of the circle formed by the water drop on the stone surface (a) and its height (H) (Fig. 2). The mathematical expression used is:

$$
\theta=2 \operatorname{arctg} \frac{2 H}{a}
$$

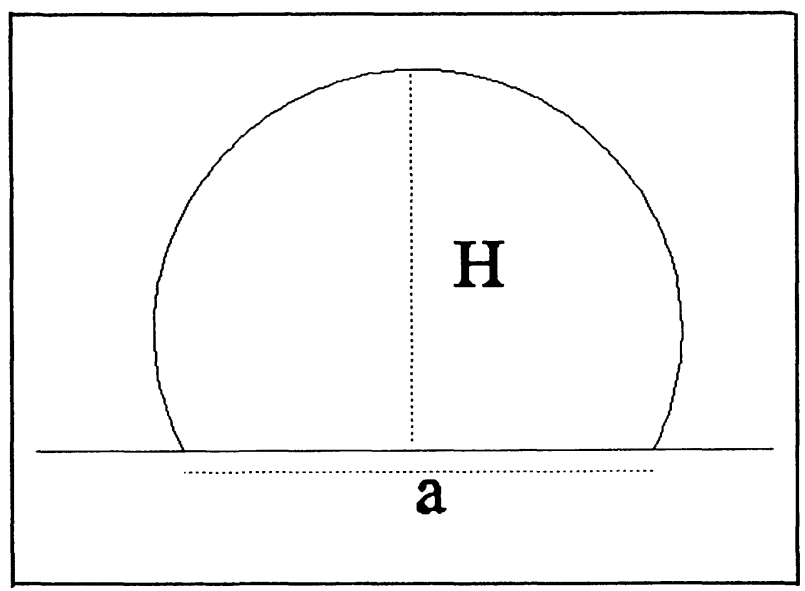

Fig.2.- Se recoge en esta figura las dimensiones a y $\mathrm{H}$ medidas para el cálculo del ángulo de contacto.

Fig.2.- The figure shows " $a$ " and " $H$ " dimensions measured for calculating the contact angle.

\section{Measurement procedure}

A $5 \mu$ water drop is dropped on the treated surface from a height of $1 \mathrm{~cm}$. The values of " $a$ " and " $H$ " are then measured with the help of a calibrated reticule magnifying glass.

An average of ten measurements per sample is normally enough representative for carbonate types.

Water vapour permeability is defined as the amount of vapour per time and surface unit flowing through a body of a given thickess in stationary conditions; between two parallel surfaces and under the effect of a difference in vapour partial pressure between the two surfaces (Normal 21/85). 
Es sabido que un requisito fundamental en un tratamiento de conservación, aplicado a una piedra, es que la deje transpirar, es decir, que permita al agua que está en su interior (humedad natural, humedad capilar, etc.), pueda salir al exterior en forma de vapor. La facilidad o dificultad con la que se va a producir esta transferencia se mide precisamente con el cálculo de la permeabilidad al vapor de agua.

Esta propiedad va a depender de una serie de factores, unos ajenos a la piedra, como son las condiciones ambientales, que condicionan el gradiente de presión por el que se produce el flujo del vapor, y otros que dependen de la naturaleza de la piedra (Guéguen y Palciauskas, 1992).

De los factores intrínsecos a la piedra destaca la porosidad (Grolier et al., 1990; Quénard y Sallée, 1991), influyendo no sólo el valor de la misma (porosidad abierta) sino también el modelo tridimensional y el grado de conectividad de los distintos espacios vacíos (Esbert y Díaz Pache, 1993).

\section{Ensayo}

En este trabajo la medida de la permeabilidad al vapor de agua se ha realizado empleando unos permeámetros, cuyas dimensiones están normalizadas (Normal 21/85) y que se representan esquemáticamente en la Fig. 3. También se aprecia en esta figura la posición de la probeta (1).

Para que se produzca un flujo de vapor de agua entre el interior y el exterior del permeámetro es necesaria la existencia de un gradiente de presión. Esta diferencia de presión se logra introduciendo los permeámetros en recipientes estancos con gel de sílice (H.R.=0\%). En el interior de los permeámetros se coloca un algodón embebido en agua destilada (Fig. 3, (2)) para conseguir que la humedad relativa en el interior sea del $100 \%$.

El aparato representado en la Fig. 3, se introduce en el interior de una cámara climática para mantener la temperatura constante a lo largo del ensayo. A pesar de que la permeabilidad en la Norma se expresa a $20^{\circ} \mathrm{C}$, la cámara está programada a $25^{\circ} \mathrm{C}$, para que el flujo de vapor sea mayor. Así pues los valores obtenidos se corregirán para los $20^{\circ} \mathrm{C}$.

Las muestras sólo se extraen de la cámara para realizar las pesadas que se hacen cada $24 \mathrm{~h}$.

El cálculo del coeficiente de permeabilidad $\left(\mathrm{K}_{\mathrm{v}}\right)$ se
An essential prerequisite for any conservation treatment applied to stone is that it allows transpiration, i.e. that the water inside (natural moisture, capillary moisture, etc.) can come to the surface in the form of vapour. The ease or difficulty with which this transference takes place is measured by the vapour permeability calculation.

This property depends on various factors, some of which are not related to the stone, such as environmental effects conditioning the pressure gradient that produces vapour flow, while others depend on the nature of the stone (Guéguen and Palciuskas, 1992).

Porosity is one of the important intrinsic stone factors (Grolier et al., 1990; Quénard and Sallée, 1991). Not only the porosity value (open porosity), but also the three-dimensional model and the degree of connectivity among the voids have an influence (Esbert and Diaz Pache, 1993).

\section{Test}

In the present study, the water vapour permeability measurement was carried out using normalized dimensions (Normal 21/85), schematically shown in Fig. 3. The figure also shows the specimen.'s position (1).

For a flow of vapour to be produced between the inside and the outside of the permeameter, a pressure gradient must exist. This pressure difference is achieved by introducing the permeameters in desiccator with silica gel (H.R. $=0 \%)$. A piece of cotton wool soaked in distilled water is placed inside the permeameters (Fig. 3, (2)) to achieve 100\% relative humidity inside.

The device shown in Fig. 3 is introduced in a climatic chamber in order to maintain constant temperature throughout the test. Although Standard permeability is set at $20^{\circ} \mathrm{C}$, the chamber is programmed at $25^{\circ} \mathrm{C}$, in order to produce a greater flow of vapour. The obtained values must therefore be corrected for $20^{\circ} \mathrm{C}$.

The samples are only taken out of the chamber for weighing, which is done every $24 h$.

The permeability coefficient $(K)$ is calculated in 
realiza según la ley de Darcy, que se expresa de forma matemática por la siguiente ecuación:

$$
\mathrm{Q}=\mathrm{K}_{\mathrm{v}} \frac{\Delta \mathrm{P} . \mathrm{S}}{\mathrm{L}} \quad \mathrm{K}_{\mathrm{v}}=\frac{\mathrm{Q} \cdot \mathrm{L}}{\Delta \mathrm{P} \cdot \mathrm{S}}
$$

Q:Caudal, expresado como el incremento (negativo) de masa por unidad de tiempo.

$\mathrm{K}:$ Coeficiente de permeabilidad.

$\Delta \mathrm{P}$ :Gradiente de presión parcial de vapor de agua entre las dos caras de la probeta.

S:Superficie de la muestra expuesta al vapor.

L:Espesor de la muestra.

Pero como ya se dijo con anterioridad el valor calculado es para una temperatura de $25^{\circ} \mathrm{C}$ y se debe transformar para una temperatura de $20^{\circ} \mathrm{C}$. Esta transformación se realiza utilizando la siguiente ecuación matemática:

$$
\mathrm{K}_{\mathrm{v} 20^{\circ} \mathrm{C}}=\mathrm{K}_{\mathrm{v25^{ \circ } \mathrm { C }}} \frac{\mathrm{P}_{20^{\circ} \mathrm{C}}}{\mathrm{P}_{25^{\circ} \mathrm{C}}}
$$

$P 20^{\circ} \mathrm{C}:$ Presión parcial de vapor de agua a $20^{\circ} \mathrm{C}(=17.535$ $\mathrm{mmHg}$ ).

$P_{v 25^{\circ} \mathrm{C}:}$ Presión parcial de vapor de agua a $25^{\circ} \mathrm{C}(=23.756$ $\mathrm{mmHg}$ ).

Cuando se mide la permeabilidad al vapor de agua en muestras tratadas, se hace de manera que la cara tratada quede enfrentada al algodón empapado en agua destilada, que se encuentra en el interior del permeámetro, tal como muestra la Fig. 4.

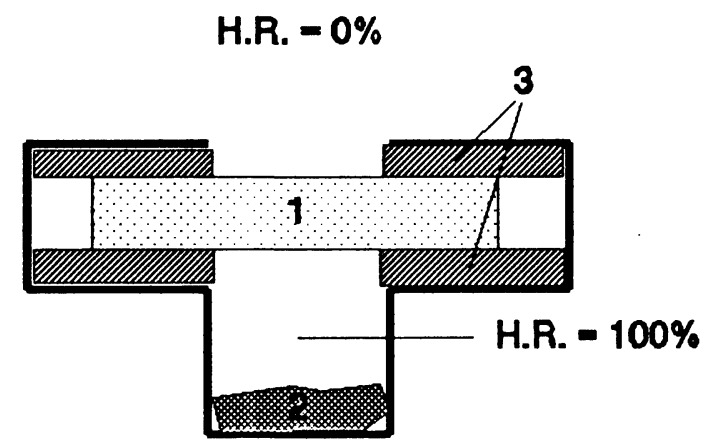

Fig.3.-Esquema del permeámetro para la medida de la permeabilidad al vapor de agua 1.- Probeta; 2.- Algodón con agua destilada; 3.- Aislante.

Fig.3.-Schematic drawing of permeameter for measuring vapour permeability. 1.- Specimen; 2.- Cotton wool with distilled water; 3.- Insulator. accordance with Darcy's law, whose mathematical expression is:

$$
Q=K_{\nu} \frac{\Delta P . S}{L}
$$$$
K_{v}=\frac{Q \cdot L}{\Delta P \cdot S}
$$

Q:Flow, expressed as the (negative) increment of mass per time unit.

$K_{v}:$ Permeability coefficient.

$\Delta P$ :Vapour partial pressure gradient between the two sides of the specimen.

$S:$ Specimen surface exposed to vapour.

L:Specimen thickness.

As mentioned above, however, the calculated value is for a temperature of $25^{\circ} \mathrm{C}$, and must be transformed to $20^{\circ} \mathrm{C}$. This transformation is performed using the following mathematical equation:

$$
K_{v 20^{\circ} \mathrm{C}}=K_{v 25^{\circ} \mathrm{C}} \frac{P_{20^{\circ} \mathrm{C}}}{P_{25^{\circ} \mathrm{C}}}
$$

$P_{v 20^{\circ} \mathrm{C}}:$ Vapour partial pressure at $20^{\circ} \mathrm{C}=17,535$ $\mathrm{mmHg}$ ).

$P_{v 25^{\circ} \mathrm{C}}:$ Vapour partial pressure at $25^{\circ} \mathrm{C}(=23,756$ $\mathrm{mmHg}$ ).

The water vapour permeability of treated samples is measured in such a way that the treated face confronts the cotton wool soaked in distilled water, which is inside the permeameter, as shown in Fig. 4.

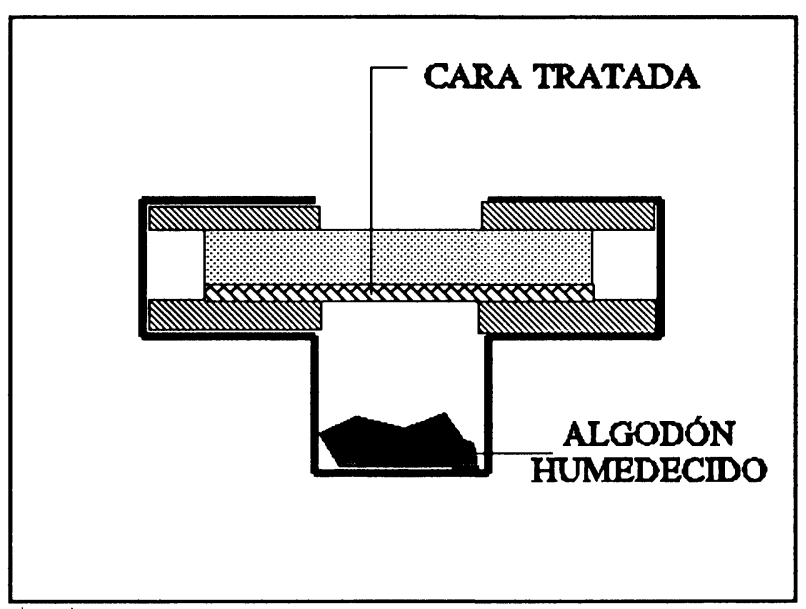

Fig.4.- Esquema en el que se muestra la posición de la cara tratada de la probeta respecto al algodón humedecido.

Fig.4.- Schematic drawing showing position of the specimen's treated face with respect to the soaked cotton wool. 
En este trabajo se han realizado medidas en los dos sentidos, es decir, con la cara tratada colocada en sentido contrario al algodón humedecido y colocada en el mismo sentido, con el fin de conocer si el tratamiento opone la misma resistencia a la entrada de vapor de agua en la piedra que a la salida del mismo.

\section{3.- MATERIALES ENSAYADOS}

Como se dijo en la introducción, los materiales seleccionados son dos piedras carbonatadas la caliza de Hontoria y la dolomía de Laspra, utilizadas en el patrimonio arquitectónico de Castilla - León y de Asturias respectivamente.

La elección de estas dos piedras, ha venido motivada porque ambas se han utilizado en monumentos ubicados en ambientes muy contaminados, en los que su protección superficial será necesaria en breve plazo. Además de ser representativas de medios porosos (presentan porosidades de alrededor del $32 \%$ la piedra de Laspra y alrededor del $23 \%$ la de Hontoria), muestran un sistema poroso muy distinto la una de la otra (Figs. 5a, 5b y 6). La dolomía de Laspra, tiene un sistema poroso, formado por pequeños canalículos, finos y tortuosos (Fig. 6a); el mayor porcentaje de porosidad corresponde a poros de radio medio de alrededor de $0,5 \mu \mathrm{m}$., con accesos en cuello de botella. Por ello presenta un porcentaje importante de porosidad atrapada según puede observarse en el histograma de la Fig. 7, obtenido mediante porosimetría de mercurio. Al ser un material de textura micrítica (tamaño de grano $<4 \mu \mathrm{m}$.), los espacios vacíos (microporos), se encuentran repartidos por toda la masa rocosa.

La caliza de Hontoria es una roca con poros móldicos, algunos de grandes dimensiones, observables a simple vista. $\mathrm{El}$ análisis porométrico revela que los macroporos (radio de acceso mayores de 7,5 $\mu \mathrm{m}$.) están comunicados por conductos más estrechos (Fig. 5b), microporos (radio de acceso menores de 7,5 $\mu \mathrm{m}$.) (Fig. 6b). La porosidad atrapada es mucho menor que en la piedra de Laspra, no supera el $50 \%$ del total de la porosidad abierta (Fig. 8). La porosidad más abundante se localiza entre los granos, pero también son importantes los poros ubicados en el seno de los granos fósiles. El radio medio de poro se sitúa alrededor de 3.5 $\mu \mathrm{m}$. La macroporosidad (poros con accesos superiores a $7,5 \mu \mathrm{m}$.) representa $1 / 3$ del volumen poroso.

La porosidad y configuración tridimensional del espacio poroso son dos aspectos fundamentales a tener en cuenta en los materiales rocosos y que condiciona, en gran medida, las propiedades hídricas (Valdeón et al., 1992) y por tanto la permeabilidad al vapor de agua de las rocas (Quénard y Sallée, 1991).
Two-way measurements have been performed in the present study; i.e., with the treated face in opposite and equal directions to the moistened cotton wool, in order to establish whether the treatment offers the same resistance when the vapour enters and exits the stone.

\section{3.- TESTED MATERIALS}

As mentioned in the introduction, the selected materials are two types of carbonate stone: Hontoria limestone and Laspra dolomite, used in buildings belonging to the architectural heritage of Castilla León and Asturias, respectively.

These types of stone were chosen because both had been used for monuments located in heavily polluted areas, in which superficial protection will soon be required. In addition to being representative of porous environments (approximate porosities of $32 \%$ for Laspra stone and 23\% for Hontoria stone), their porous systems are very different (Figs. 5a, 5b, and 6). Laspra dolomite has a porous system formed by small, fine and tortuous channels (Fig. 6a); the highest porosity percentage corresponds to pores of an average radius of about $0.5 \mu \mathrm{m}$, with bottleneck openings. Thus it has a high percentage of trapped porosity, as shown in the histogram in Fig. 7, obtained by means of mercury porosimetry. Since the material has a micritic texture (grain size $44 \mu \mathrm{m}$ ), voids (micropores) are distributed throughout the stone.

Hontoria limestone is a type of rock with moldic pores, some of them very large and visually perceivable. Porometric analysis reveals that the macropores (porethroat radius of over $7.5 \mu \mathrm{m}$ ) are communicated by means of narrower conducts (Fig. 5b), micropores (pore-throat radius of under $7.5 \mu \mathrm{m}$ ) (Fig. 6b). Trapped porosity is much less than in the Laspra stone, not exceeding 50\% of the open porosity (Fig. 8). The most abundant porosity is to be found between the grains, but the pores located in the midst of the fossil grains are also important. Average pore radius is about $3.5 \mu$ $\mathrm{m}$. Macroporosity (pores with openings of over $7.5 \mu \mathrm{m}$ ) represents $1 / 3$ of the pore volume.

Porosity and three-dimensional configuration of the pore space are essential aspects of rock materials, and to a large extent condition their hydric properties (Esbert and Montoto, 1993), and thus the vapour permeability of rocks (Quénard and Sallée, 1991). 

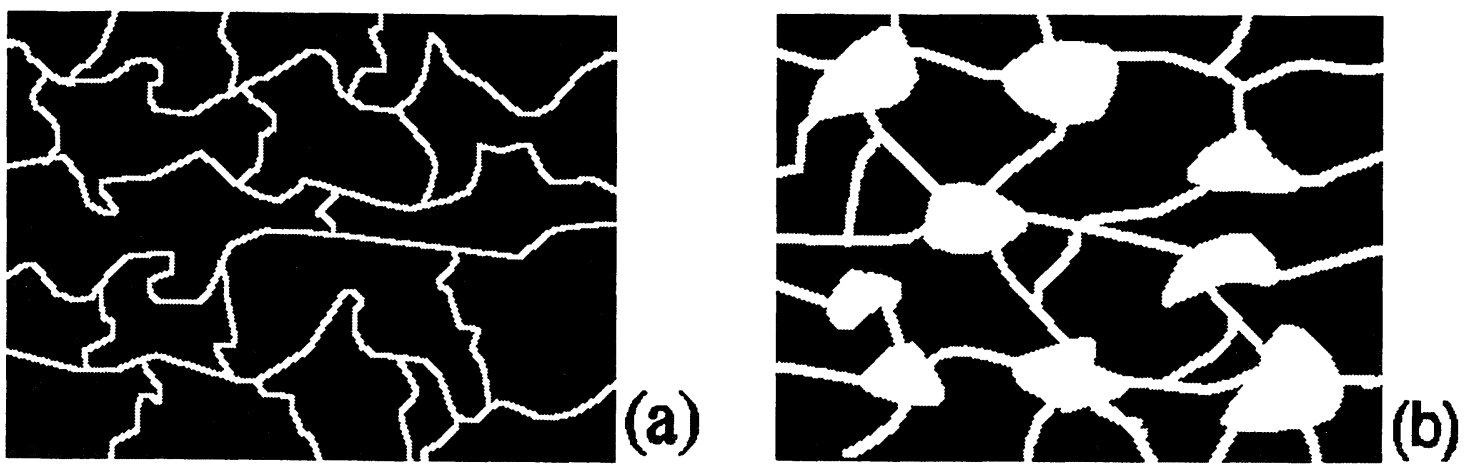

Fig.5.- Esquema idealizado del sistema poroso y de la comunicación entre poros (en blanco), a) de la dolomía de Laspra y b) de la caliza de Hontoria.

Fig.5.- Ideal schematic representation of pore system and communication between pores (in white) of Laspra dolomite (a) and Hontoria limestone (b).

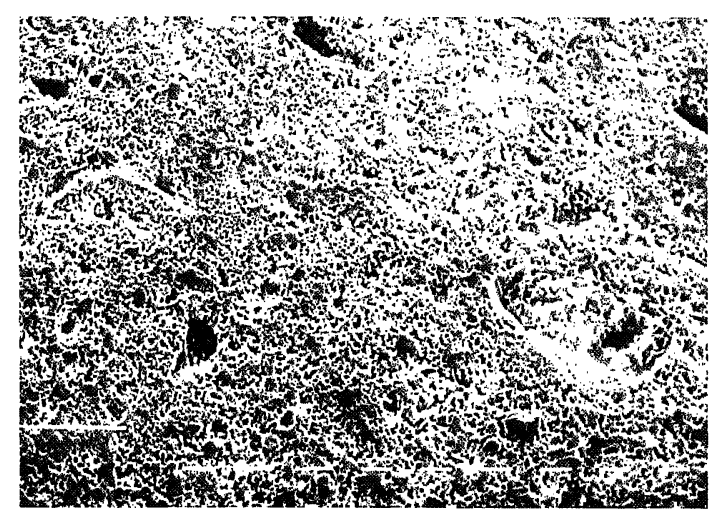

$\mathbf{a}$

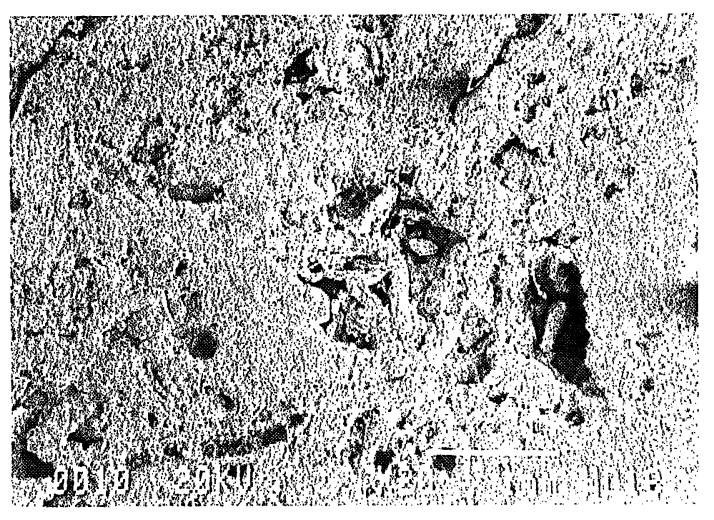

b

Fig.6.- Aspecto al MEB de la piedra de : a) Laspra y b) Hontoria. Obsérvese el distinto tamaño de los poros y textura de una y otra variedad.

Fig.6.- SEM appearance of Laspra stone (a) and Hontoria stone (b). Note the different pore size and texture from one variety to the other. 


\section{PIEDRA DE LASPRA}

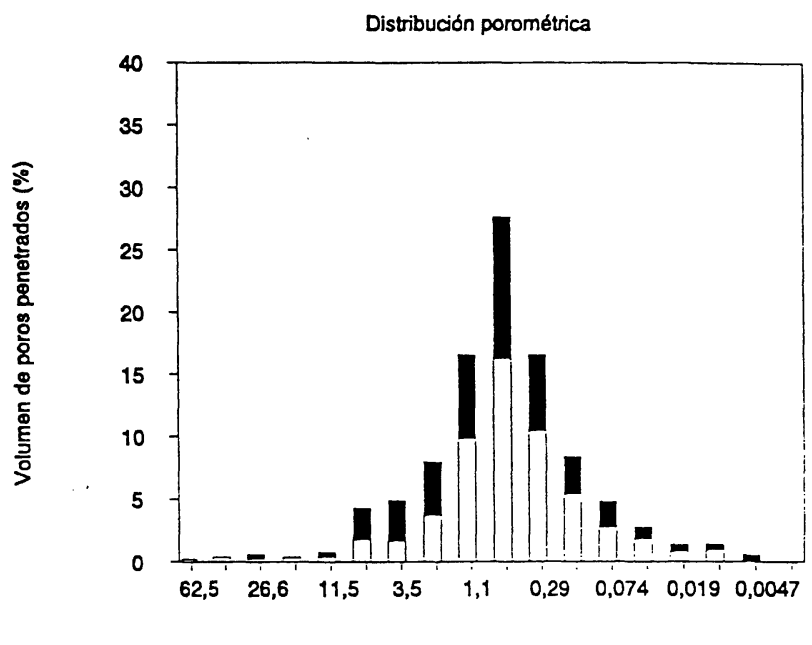

Radio de acceso de poro $(\mu \mathrm{m})$

$\square$ POROSIDAD UBRE $\square$ POROSIDAD ATRAPADA

Fig.7.- En el histograma se recoge la distribución porométrica de la dolomía de Laspra (Esbert y Díaz-Pache,1993). Prácticamentetodos los poros son inferiores a 7,5 $\mu \mathrm{m}$. (microporosidad).

Fig.7.-Histogram showing the porometric distribution of Laspra dolomite (Esbert and Díaz-Pache, 1993). Practically all pores are under $7.5 \mu \mathrm{m}$ (microporosity).

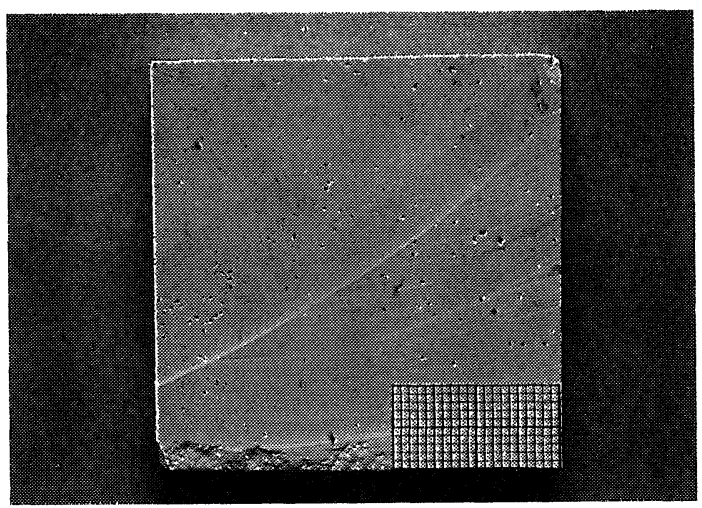

a

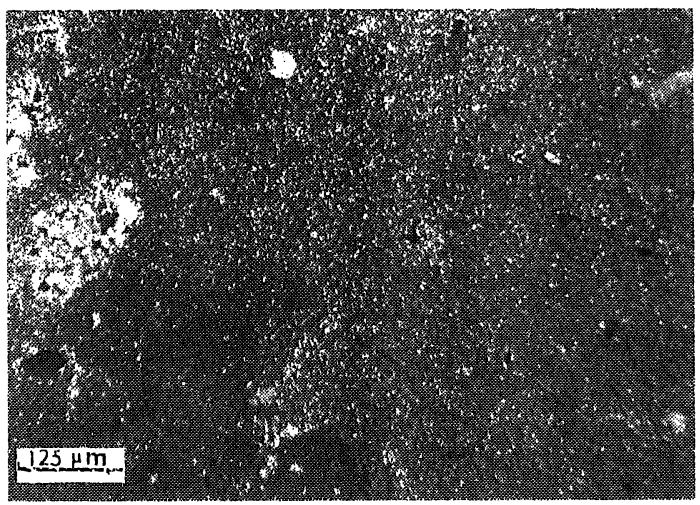

PIEDRA DE HONTORIA

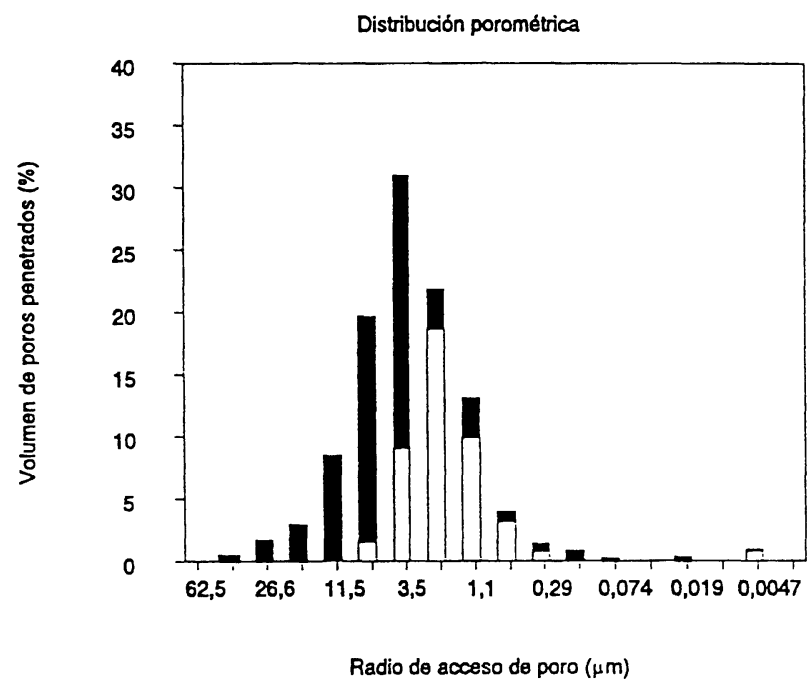

Fig.8.- En el histograma se recoge la distribución porométrica de la caliza de Hontoria (Esbert y Díaz-Pache, 1993). Como puede observarse, el tamaño medio de los poros es superior al de la dolomía de Laspra.

Fig.8.- Histogram showing the porometric distribution of Hontoria limestone (Esbert and Díaz-Pache, 1993). As shown, the average pore size is greater than of Laspra dolomite.
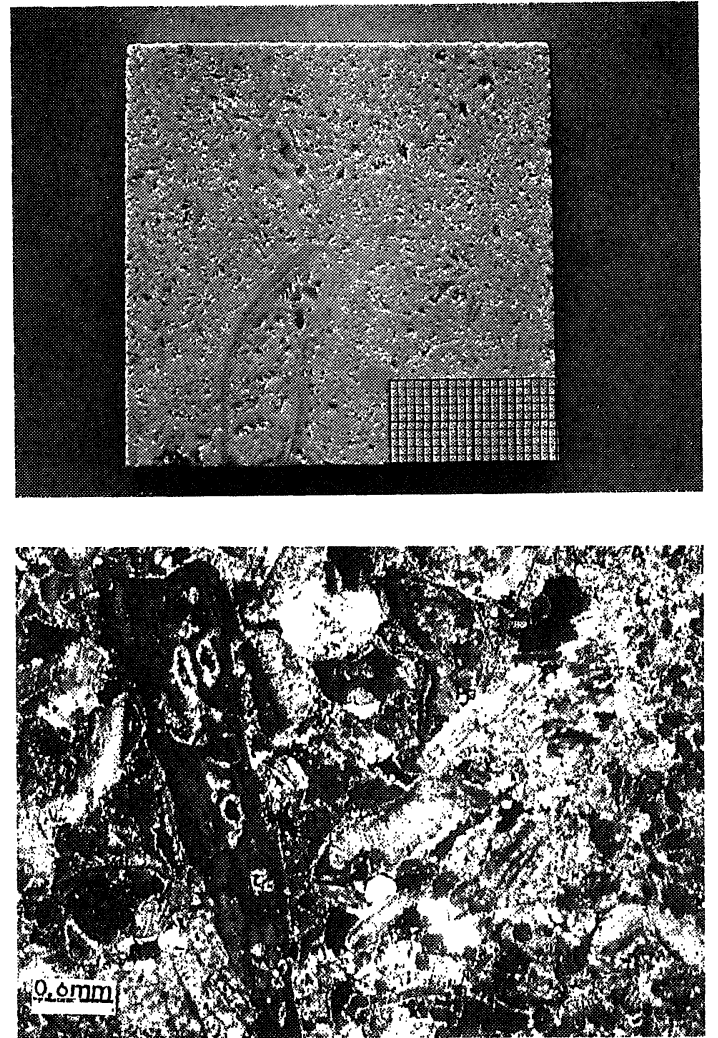

d

Fig.9.- Aspecto macroscópico de: a) dolomía de Laspra, b) caliza de Hontoria.La observación con el microscopio de polarización permite comparar las diferencias texturales entre la piedra de Laspra (c) y la de Hontoria (d).

Fig.9.- Macroscopic appearance of: a) Laspra dolomite, b) Hontoria limestone. Observation under the polarization microscope allows comparison of textural differences between Laspra stone (c) and Hontoria stone (d). 
La Fig. 9 muestra el aspecto macroscópico de la piedra de Laspra y Hontoria (9a y b) así como la textura de las mismas al microscopio de polarización (9c y d). Resalta el aspecto más uniforme de la dolomía de Laspra en relación con la caliza de Hontoria.

La petrografía, propiedades físicas, químicas y alterológicas de estas rocas han sido descritas en diversos trabajos. (Esbert y Marcos, 1983; Grossi, 1986; Menéndez et al., 1988; Marcos et al., 1993; ...

\section{4.- PRODUCTOS APLICADOS}

Se han aplicado hidrofugantes de distinta naturaleza química de dos casas comerciales diferentes: Bayer y Th. Goldschmid. El nombre comercial, su composición y la abreviatura se representa en la Tabla I.
Fig. 9 shows the macroscopic appearance of Laspra and Hontoria stone (9a and $b$ ), together with texture, under the polarization microscope (c and d). This highlights the more uniform appearance of Laspra dolomite with respect to Hontoria limestone.

The petrography and physical, chemical and alterological properties of these rocks have been described in several studies (Esbert and Marcos, 1983; Grossi, 1986; Menéndez et al., 1988; Marcos et al., $1993 ; \ldots)$

\section{4.- APPLIED PRODUCTS}

Hydrofuging products of different chemical composition, supplied by two manufacturers -Bayer and Th. Goldschmidt-..-have been applied. Trade names, composition and abbreviations are indicated in Table I.

Tabla I

\begin{tabular}{||c|c|c||}
\hline NOMBRE COMERCIAL & NATURALEZA QUÍMICA & $\begin{array}{c}\text { ABREVIATURA } \\
\text { EN EL } \\
\text { TEXTO }\end{array}$ \\
\hline BAYSILONE LO-N & ALCOXI-SILOXANO & LO-N \\
\hline BAYSILONE LF & $\begin{array}{c}\text { COPOLÍMERO } \\
\text { SILOXANO ACRILATO }\end{array}$ & LF \\
\hline TEGOSIVIN HL-40 & SILOXANO & HL-40 \\
\hline
\end{tabular}

\section{Características químicas}

Todos los compuestos empleados son silicorgánicos, y se conocen con el nombre general de siliconas. Forman un grupo muy amplio, todos ellos tienen en común estar compuestos por átomos de silicio. Este elemento, tiene unas propiedades químicas similares al carbono, ya que pertenecen al mismo grupo de la tabla periódica (IV B). Ambos tienen la propiedad de poder unir sus átomos, a través de un enlace covalente fuerte, que les permite formar grandes cadenas.

Estos compuestos silicorgánicos al hidrolizarse forman sílice que precipita en forma amorfa. Esta sílice tiene unos radicales polares que le permiten unirse, por fuerzas electrostáticas, al substrato rocoso. Además de estos grupos polares, presentan radicales no polares que se orientan hacia el exterior y son los que les confieren su cualidad hidrorrepelente (Fig. 10).

\section{Chemical characteristics}

All the compounds used above are silicorganic, and are known under the general name of silicones. They belong to a very large group, and all of them are made up of silicon atoms. This element has similar chemical properties to carbon, since both belong to the same group of the periodic table (IV B). Both are able to bind atoms through a strong covalent link that allows them to form large chains.

These silicorganic compounds hydrolyze forming silica that precipitates in amorphous form. The silica has polar radicals allowing it to bind to the stone substrate by means of electrostatic forces. In addition to these polar groups, it has non-polar radicals that are aimed towards the outside, which give it its waterproofing quality (Fig. 10). 


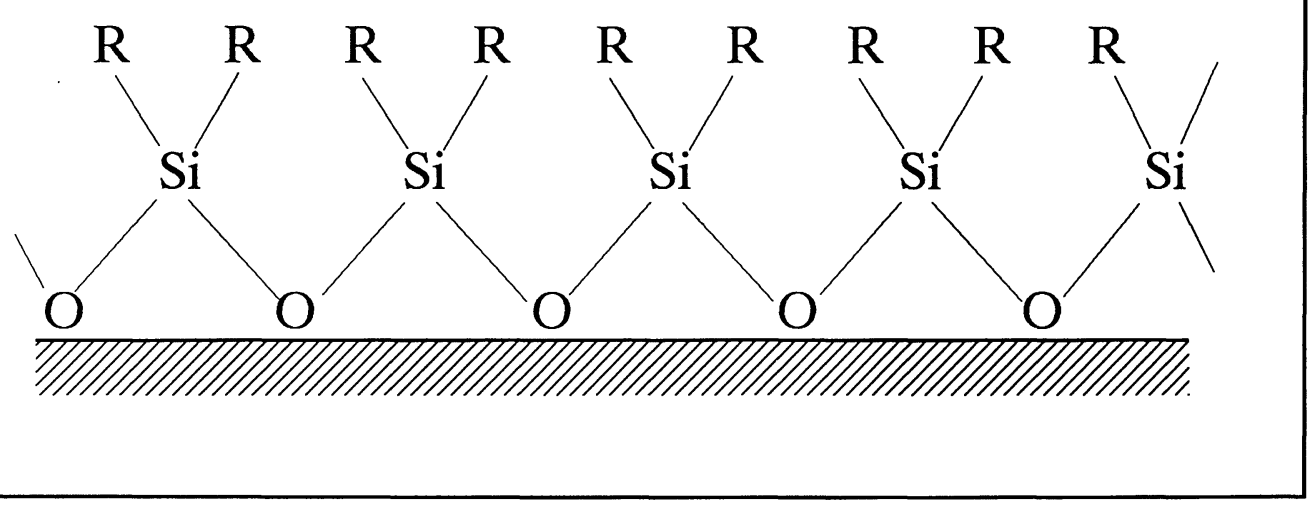

Fig.10.- Esquema en el que se representa la orientación de los tratamientos hidrorrepelentes sobre la superficie de la piedra.

Fig.10.- Schematic representation showing the orientation of water repellent treatments on the stone surface.

\section{Requisitos de los hidrofugantes}

A la hora de emprender la protección de un substrato rocoso, a los productos hidrofugantes o hidrorrepelentes se les debe exigir una serie de propiedades (Amoroso y Fassina, 1983):

-Que no cambie ni el color ni la apariencia de la piedra.

-Debe penetrar suficientemente en el interior de la piedra, de manera que alcance a la roca sana y no se quede en la parte dañada.

-El producto debe permanecer en la piedra cuando polimeriza (se endurece).

-Debe impedir la entrada de la humedad, pero debe dejar "respirar" a la piedra, es decir, ésta tiene que ser permeable al vapor de agua.

-El comportamiento térmico del producto sólido debe ser similar al de los componentes de la piedra para evitar que se produzcan fracturas del material.

-Debe proteger a la piedra de la acción de los contaminantes y de los agentes biológicos.

-Debe ser inerte, es decir, no debe reaccionar con la piedra.

\section{Modo de aplicación}

A causa de su elevada viscosidad, a la hora de aplicar los diferentes productos hidrorrepelentes, deben ser

\section{Hydrofuging agent prerequisites}

Hydrofuging or waterproofing products used for protecting a stone substrate must have a series of properties (Amoroso and Fassina, 1983):

-They must not alter the stone's colour or appearance.

-Penetration inside the stone should be sufficient to reach the healthy core and not remain in the damaged part.

-The product should remain on the stone after polymerizing (hardening).

-It should prevent moisture from entering, but let the stone "breathe", i. e., the stone should be permeable to water vapour.

-The product's thermal behaviour should be similar to that of the stone's components in order to avoid fractures in the material.

-It should protect the stone from the action of pollutants and biological agents.

-It must be inert, i.e., not react with the stone.

\section{Form of application}

Due to their high viscosity, when applying the different water repellent products, they must be dissolved in 
disueltos para lograr una suficiente penetración en la roca.

Como disolventes se han empleado 1:1:1 Tricloroetano (para el Baysilone LF) y White Spirit (para el Baysilone LO-N y el Tegosivin HL-40). El emplear dos disolventes diferentes se debió a que el Baysilone LF presenta problemas de polimerización con el White Spirit.

En un principio se empleó como disolvente para el Baysilone LF gasolina, como recomendaba la firma comercial (primero gasolina sin $\mathrm{Pb}$ y posteriormente gasolina super), pero ésta presentaba el problema de producir brillos en la superficie de las piedras así tratadas. La presencia de estos brillos es un importante inconveniente para emplear este tratamiento en obra, ya que siguiendo las teorías de la restauración de Cesare Brandi (1972) "Carta del Restauro", los tratamientos aplicados a piedras monumentales no deben inducir cambios en el aspecto externo de las mismas.

La concentración de los distintos productos en sus correspondientes disolventes fue: Baysilone LO-N: 1/15 en White Spirit; Baysilone LF: $1 / 10$ en 1:1:1:

Tricloroetano; Tegosivin HL-40: 1/10 en White Spirit.

Los tratamientos se han aplicado sobre las distintas muestras de piedra por pincel para aproximarse a la realidad de aplicación en obra.

\section{5.- RESULTADOS}

\section{Ángulo de contacto}

Para las piedras sin tratar el valor de este ángulo entre la piedra y el agua es 0 ; la gota es absorbida de forma instantánea por la piedra.

En la Tabla II se recogen los valores del ángulo de contacto obtenidos para las dos piedras ensayadas con los diversos tratamientos. order to achieve adequate stone penetration

The following solvents have been used: 1:1:1 trichloroethane (for Baysilone LF) and White Spirit (for Baysilone LO-N and Tegosivin HL-40). Two different solvents were used, as polymerization problems arise when dissolving Baysilone with White Spirit.

Intitially, petrol was used to dissolve Baysilone $L F$, as indicated by the the manufacturer (unleaded petrol was used first, followed by standard high-octane petrol), but this produced colour alterations in the Laspra dolomite.

Concentration of the different products in their respective solvents was as follows: Baysilone LO-N: 1/15 in White Spirit; Baysilone LF: 1/10 in 1:1:1 Trichloroethane; Tegosivin HL-40: 1/10 in White Spirit.

The different samples were treated by Brush application.

\section{5.- RESULTS}

\section{Contact angle}

For non-treated stones, the value of this angle between the stone and water is 0; the water-drop is absorbed instantaneously by the stone.

Table II shows contact angle values obtained for the two types of tested stones with the different treatments:

\section{Tabla II Table II}

Valores obtenidos en la medida del ángulo de contacto para los distintos tratamientos y variedades rocosas ensayadas.

(Contact angle values obtained for the different treatments and varieties of tested rocks.)

\begin{tabular}{||c|c|c|c|c||}
\cline { 2 - 5 } \multicolumn{1}{c|}{} & \multicolumn{4}{c||}{ ÁNGULO DE CONTACTO } \\
\hline \hline TIPO DE ROCA & SIN TRATAR & LO-N & LF & HL-40 \\
\hline HONTORIA & 0 & 103,2 & 102,3 & 110,6 \\
\hline LASPRA & 0 & 114,5 & 91,7 & 130,2 \\
\hline
\end{tabular}


A la vista de los resultados obtenidos para las piedras sin tratar y tratadas cabe destacar en primer lugar el aumento tan importante que se produce en el valor de esta propiedad en las piedras tratadas, siendo el caso más espectacular el de la dolomía de Laspra tratada con el Tegosivin HL-40, que del valor 0 , de la probeta sin tratar, pasa a tener un valor de $130^{\circ}$.

También se observa que el ángulo de contacto es mayor para la piedra de Laspra que para la de Hontoria con la excepción de las piedras tratadas con el copolímero (Baysilone LF).

Cabe destacar el paralelismo que muestran los valores obtenidos con un mismo tratamiento, en Laspra y Hontoria. Así, el valor más alto del ángulo de contacto tanto para Laspra como para Hontoria se alcanza con el siloxano HL-40; el valor intermedio con el siloxano LO-N y el más bajo, en los dos tipos de rocas, con el copolímero LF. A la vista de los resultados es evidente que esta propiedad está más relacionada con el tipo de hidrofugante empleado que con las características texturales del sustrato pétreo.

\section{Permeabilidad al vapor de agua}

Las Tablas III y IV recogen los valores obtenidos para la permeabilidad al vapor en las piedras sin tratar y tratadas respectivamente.
On the basis of the results obtained for treated and non-treated stones, the first point to be emphasized is the significant increase in the value of this property in the treated stones, most spectacularly in the case of Laspra dolomite treated with Tegovisin HL-40, whose non-treated specimen value of 0 rises to $130^{\circ}$.

It is also shown that the contact angle is higher for Laspra stone than Hontoria stone, with the exception of stones treated with the copolymer (Baysilone LF).

Also important is the correlation of values obtained with the same treatment for Laspra and Hontoria. Thus the highest contact angle value both for Laspra and Hontoria is reached with siloxane HL-40; the intermediate value is reached with siloxane LO-N; and the lowest value, in both types of rock, is obtained with copolymer LF. On the basis of these results, it is obvious that this property is more related to the type of hydrofuging product used than to the textural characteristics of the stone.

\section{Water vapour permeability}

Tables III and IV show water vapour permeability values obtained for treated and non-treated stones respectively.

\section{Tabla III Table III}

Valores de la permeabilidad al vapor para las piedras de Laspra y de Hontoria $\sin$ tratar en $\mathrm{g} / \mathrm{m}^{2} 24 \mathrm{~h}$.

(Water vapour permeability values for non-treated Laspra and Hontoria stone in $\mathrm{g} / \mathrm{m}^{2} 24 h$.)

\begin{tabular}{|c|c|c|}
\hline ROCAS & LASPRA & HONTORIA \\
\hline $\mathrm{K}_{\mathrm{v}}\left(\mathrm{g} / \mathrm{m}^{2} 24 \mathrm{~h}\right)$ & 181,50 & 189,09 \\
\hline
\end{tabular}

\section{Tabla IV Table IV}

Valores de la permeabilidad al vapor (Normal 21/85) en las piedras de Hontoria Y Laspra, tratada con diferentes hidrorrepelentes y sin tratar (STR)

(Water vapour permeability values (Normal 21/85) for Hontoria and Laspra stone, treated with different hydro-repellents and non-treated).

\begin{tabular}{|c|c|c|c|c|}
\hline \multirow[b]{2}{*}{ TRATAMIENTOS } & \multicolumn{4}{|c|}{$K_{v}\left(g / m^{2} 24 h\right)$} \\
\hline & LO-N & $\mathbf{L F}$ & HL-40 & STR \\
\hline HONTORIA & 152,04 & 154,89 & 136,83 & 189,09 \\
\hline LASPRA & 146,34 & 156,79 & 139,68 & 181,50 \\
\hline
\end{tabular}


Los valores de la permeabilidad al vapor para las rocas sin tratar son muy similares, siendo ligeramente mayor el coeficiente de permeabilidad para la piedra de Hontoria. Estos valores son los esperados si se tiene en cuenta la ley de Poiseuille, la cual dice que el caudal de un fluido determinado a través de un cuerpo poroso, para un gradiente de presión determinado es proporcional a la cuarta potencia del radio medio de los poros (suponiéndolos cilíndricos), y se expresa matemáticamente por la siguiente ecuación:

$$
\mathrm{Q}=\frac{\pi \cdot \Delta \mathrm{P} \cdot \mathrm{R}_{4}}{8 \cdot \eta \cdot \mathrm{L}}
$$

$\eta$ :Viscosidad.

R:Radio medio de los poros.

$\Delta \mathrm{P} / \mathrm{L}:$ Gradiente de presión.

El hecho de que la diferencia entre un tipo y otro de piedra sea tan pequeña se puede deber a los valores de la porosidad, mayor en Laspra (alrededor del $30 \%$ ) que en Hontoria aproximadamente un $20 \%$ ).

Un hecho importante es el que la permeabilidad medida en las piedras tratadas en una dirección y en otra no presenta cambios importantes con la excepción de las piedras tratadas con el copolímero, en las que hay una pérdida muy importante cuando el flujo de vapor va de la cara no tratada a la tratada. Este último hecho podría deberse a la diferente profundidad de penetración de los productos ensayados. El Baysilone LF es más filmógeno y denso que los otros dos y por tanto penetra menos en la piedra. Un producto que penetra poco, afectará muy superficialmente a la roca tratada, mientras que los tratamientos con una mayor profundidad de penetración, como es el caso del resto de los ensayados, afectarían por lo menos a todo el espesor de la muestra ensayada $(1 \mathrm{~cm})$.

Cuando la probeta esta impregnada en todo su espesor $(1 \mathrm{~cm})$ el vapor de agua tendría igual dificultad al circular en cualquier dirección por el interior de la piedra. Si la parte afectada por el tratamiento es sólo una parte superficial del centímetro ensayado y además forma una barrera, el vapor de agua tendría menos dificultad en circular por el interior de ésta, por la parte no tratada, que en poder salir al exterior de la misma.

En cuanto a las piedras tratadas, para correlacionar más fácilmente los cambios que se producen en su permeabilidad se van a expresar los resultados en forma de porcentaje, como recoge la Tabla V.
The water vapour permeability values for non-treated specimens are very similar, the permeability coefficient for Hontoria stone being slightly higher. These values are expectable when considering Poiseuille's law, in accordance with which the flow of a given fluid through a porous body for a given pressure gradient is proportional to the fourth power of the mean radius of the pores (supposing them to be cylindrical). This is mathematically expressed by the following equation:

$$
Q=\frac{\pi \cdot \Delta P \cdot R_{4}}{8 . \eta \cdot L}
$$

$\eta:$ Viscosity.

$R:$ Mean radius of pores.

$\triangle P / L:$ Pressure gradient.

The fact that the difference between the stone types is so small may be due to the porosity value, which is higher in Laspra stone (about 30\%) than in Hontoria (about 20\%).

An important fact is that the average permeability of stones treated in both directions does not show significant changes, with the exception of stones treated with the copolymer, where an important loss occurs when the vapour flow is directed from the non-treated to the treated face. This might be due to the different penetration depth of the tested products. Baysilone LF is more filmogenous and dense than the other two products, and thus has a lower penetration ability. A product with little penetration will only affect the treated stone in a very superficial manner, while treatments with a higher penetration degree, such as those used on the remaining samples, would at least affect the complete thickness of the tested sample $(1 \mathrm{~cm})$.

When the whole thickness of the specimen $(1 \mathrm{~cm})$ is impregnated, the vapour would have the same level of difficulty in circulating in any direction inside the stone. If the area affected by the treatment only covers a superficial part of the tested centimetre and in addition to this it creates a barrier, the vapour would find it less difficult to circulate inside de non-treated part than to come to the surface.

As regards the treated stones, in order to correlate their permeability changes more easily, results will be expressed in percentages, as shown in Table V: 
Variación en porcentaje de la permeabilidad al vapor de agua de las piedras tratadas con diferentes productos hidrofugantes en relación con las sin tratar.

(Porcentage variation of vapour permeability in stones treated with different hydrofuging products and in nontreated stones)

\begin{tabular}{||c|c|c|c|c|}
\cline { 2 - 5 } \multicolumn{1}{c|}{} & \multicolumn{4}{c|}{ TRATAMIENTO EMPLEADO } \\
\cline { 2 - 5 } & LO-N & LF & HL-40 & STR \\
\hline \hline HONTORIA & $80,4 \%$ & $81,9 \%$ & $72,3 \%$ & $100 \%$ \\
\hline LASPRA & $80,6 \%$ & $86,3 \%$ & $76,9 \%$ & $100 \%$ \\
\hline
\end{tabular}

Se ve claramente como para un tratamiento determinado el descenso en la permeabilidad es similar, independientemente de la piedra tratada.

A la vista de estos resultados se puede deducir que la reducción de la permeabilidad está más relacionada con el tratamiento empleado que con el tipo de piedra. Sin embargo se esboza una cierta relación entre las características del sustrato rocoso y esta propiedad, como lo demuestra el mayor decremento de permeabilidad al vapor mostrado por la piedra de Hontoria frente a la de Laspra.

\section{6.- CONCLUSIONES}

-Se ha comprobado experimentalmente que:

- El ángulo de contacto y la permeabilidad al vapor de agua de las rocas tratadas están estrechamente relacionadas con el carácter hidrofugante de su superficie.

- En este sentido, y según los resultados experimentales obtenidos se puede considerar que un producto es tanto más hidrofugante cuanto mayor es el ángulo de contacto y mayor la reducción en la permeabilidad al vapor.

-En todos los casos ensayados se puede establecer una buena relación entre el grado de hidrorrepelencia de la superficie, el valor del ángulo de contacto y la permeabilidad al vapor de agua. Así, al aumentar el ángulo de contacto aumenta la hidrorrepelencia de la superficie, disminuyendo la permeabilidad al vapor de agua para todas las piedras y tratamientos. El producto más hidrorrepelente ha resultado ser el siloxano $\mathrm{HL}-40$, tanto para Laspra como para Hontoria, el menos hidrorrepelente el copolímero (LF), mostrando el siloxano LO-N una hidrorrepelencia intermedia.
It is clear that for a given treatment the decrease in permeability is similar, regardless of the stone that is treated.

On the basis of these results, we may deduce that the reduction in permeability is related more to the used treatment than to the type of stone. However, there appears to be some relationship between the characteristics of the stone substrate and this property, as shown by the higher decrease in vapour permeability of the Hontoria stone versus the Laspra stone.

\section{6.- CONCLUSIONS}

-It has been shown experimentally that:

- Contact angle and water vapour permeability of the treated stones are closely related to the waterrepellent nature of the stone's surface.

- In this respect, and according to the experimental results obtained, it may be said that the higher the contact angle and vapour permeability reduction of a given product, the greater its hydrofuging capacity.

-In all the tested cases, a good relationship may be established between the degree of hydrofuging ability of the surface and the contact angle and water vapour permeability values. Thus when the contact angle increases, so does the surface's hydrofuging capacity, while the vapour permeability decreases in all the stones and types of treatment. The most water repellent product was siloxane HL-40, both for Laspra and Hontoria stone; the least was the copolymer (LF). Siloxane LO-N showed an intermediate hydrofuging capacity. 
-Por lo anteriormente expuesto parece que la acción de un tratamiento de hidrofugación superficial es independiente de las características mineralógico texturales de la piedra sobre la que se aplica o al menos la influencia de éstas es mínima, en el caso de las rocas ensayadas (materiales carbonatados muy porosos).

-En las piedras tratadas el valor de la permeabilidad al vapor de agua es independiente del sentido en la que se mida (Apartado 2 NORMAL 21/85), con la única excepción de las piedras tratadas con el copolímero (LF). En este caso la diferencia de medida en uno $u$ otro sentido puede ser del orden del $18 \%$. Este hecho se podría explicar por la escasa penetración del tratamiento en la piedra, ya que este tratamiento es muy filmógeno y polimeriza en superficie, formando una barrera. Cuando esta barrera se dispone hacia la fuente de humedad, una vez que el vapor de agua atraviesa esta barrera no tiene dificultad para salir al exterior. Cuando esta barrera está en la posición contraria a la anterior, hacia la zona seca, el vapor de agua entra en la piedra pero después le resulta más fácil difundirse por el interior de la misma que salir al exterior, ya que la capa de tratamiento se lo dificulta.

-De los tres productos experimentados el copolímero LF es el que presenta un menor interés desde el punto de vista aplicado. Induce brillos en la superficie, es el que menos penetra (carácter filmógeno) y es el menos hidrofugante.

-Para piedras tan porosas como las del presente estudio, es recomendable emplear un numero de probetas suficientemente amplio para que las medidas experimentales resulten representativas, dada la dispersión de valores obtenidos para las distintas propiedades. Se puede considerar apropiado el empleo de 10 a 12 probetas por propiedad y ensayo.

\section{7.- AGRADECIMIENTOS}

A la Comisión Interministerial de Ciencia y Tecnología (CICYT), Proyecto PAT 91-1093-CO3-01: "Modelos de interacción piedra-tratamiento para el diagnóstico del deterioro de la piedra monumental".
-In view of the above, it would seem that the action of a superficial hydrofuging treatment is independent of the mineralogical and texture characteristics of the treated stone, or that at least the latter's influence is minimal in the case of the tested stones highly porous carbonate rocks).

-In the treated stones, the water vapour permeability value is independent of the measurement direction (Section 2 NORMAL 21/85), with the sole exception of stones treated with copolymer (LF). In the latter case the difference resulting from measuring in one direction or the other is around 18\%. This may be explained by the treatment's low penetration in the stone, since it is a highly filmogenous type of treatment and polymerizes on the surface, forming a barrier. When this barrier is oriented towards a source of moisture, once the vapour crosses the barrier it has little difficulty in getting out. When the barrier is in the opposite position, oriented towards the dry area, the vapour enters the stone but it is then easier for it to diffuse inside than to exit to the outside, since the layer of treatment product makes this difficult.

-Of the three tested products, copolymer LF is the least attractive from the experiment's point of view. It induces surface brilliance, has the lowest penetration capacity (filmogenous nature) and is the poorest hydrofuging agent.

-For stones with such a high level of porosity as those used in the present study, it is advisable to use a sufficiently wide range of specimens for experimental measurements to be representative, given the dispersion of values obtained for the different properties. The use of 10 to 12 specimens per test and property is considered adequate.

\section{7.- ACKNOWLEDGEMENTS}

The support of the Comision Interministerial de Ciencia y Tecnología (CICYT), Project No. PAT91-1093-CO3-01:

"Modelos de interacción piedra -tratamiento para el diagnóstico del deterioro de la piedra monumental", is gratefully acknowledged.

\section{BIBLIOGRAFÍA}

ALESSANDRINI, G y TABASSO, M., (1993): “La protezione de la pietra: la situazione in Italia". Science and Technology for Cultural Heritage, Vol I, n 1 Giardini Editore, Pisa 5 p.

AMOROSO, G. G. y FASSINA, V., (1983): "Stone decay and conservation". Material Science Monographs, 11. Elsevier Ed., Amsterdam, $453 \mathrm{p}$. 
BRANDI, C., (1972): “Teoría de la Restauración”. Alianza Forma, Alianza Editorial, Madrid, 147 p.

DE CASTRO, E., (1980): “Determination de l'angle de contact eau-pierre”. Doc RILEM 58 VTP 80/4.

DE WHITE, E.; VERHEYEN, A.; DE BRUYN, R. y PIEN, A. (1993): "Surface protectants for stone materials. The current situation in northen Europe". Science and Technology for Cultural Heritage, Vol. I, $\mathbf{n}^{\circ} 1$ Giardini Editore, Pisa $7 \mathrm{p}$.

ESBERT, R. M. y MARCOS, R. M., (1983): "Las piedras de la Catedral de Oviedo y su deterioración”. Col. Oficial de Aparejadores y Arquitectos Técnicos de Asturias, Gráficas Summa 147 p.

ESBERT, R. M., (1993): "The use of surface protectants for stone materials: The current situation in Spain, Portugal and South America". Science and Technology for Cultural Heritage, Vol I, $n^{\circ} 1$ Giardini Editore, Pisa pp 183-189.

ESBERT, R. M. y DÍAZ-PACHE, F., (1993): "Influencia de las características petrofísicas en la penetración de consolidantes en rocas monumentales porosas". Materiales de Construcción, Vol 230 n43, Madrid, pp. 25-36.

GROLIER, J.; FERNANDEZ, A; HUCHER, M. y RISS, J. (Ed.) (1990): “Les propiétés physiques des roches. Théories et modèles". Ed. Màsson, París, 456 p.

GROSSI, C. M., (1986): "Ensayos de tratamiento en materiales rocosos de la Catedral de Oviedo". Tesis de Licenciatura, Dpto. Petrología, Univ. Oviedo, 122 p.

GUÉGUEN, Y. y PALCIAUSKAS, V., (1992): “Introduction à la physique des roches”. Ed. Hermann, París, 299 p.

MARCOS, R. M., ESBERT, R. M., ALONSO, F. J. y DÍAZ - PACHE, F., (1993):"Características que condicionan el comportamiento de la caliza de Hontoria (Burgos), como piedra de construcción". Boletín Geológico y Minero, Vol 104, n5, pp. 587-597.

MENÉNDEZ, B., ORDAZ, J. y ALONSO, F., (1988): “Observación del sistema poroso de rocas carbonatadas al microscopio electrónico de barrido". Estudios Geológicos, n 44, pp. 189-197.

NORMAL 21/85, CNR-ICR (1985): “Permeabilitá al vapor d' acua". Roma, 5 p.

QUÉNARD, D. y SALLÉE, H., (1991): "Le transfert isotherme de la vapeur d'eau condensable dans les matériaux microporeux du bâtiment”. Cahiers du CSTB, 2525. Paris. 20 p.

ROSSI MANARESI, R. (1993): "The use of stone protectives from antiquity to the beginnig of the industrial revolution". Science and Technology for Cultural Heritage, Vol I, $n^{\circ} 1$ Giardini Editore, Pisa 6 p.

VALDEÓN, L., ESBERT, R. M. y GROSSI, C. (1992): “Hydric properties of some spanish building stones: a petrophisical interpretation. Materials Research Society Symposium, Vol. 267, pp. 911-916. 